\title{
REFLECTIONS ON THE STRUCTURE OF CROATIAN MEASURES FOR LIMITING THE DEDUCTIBILITY OF FINANCIAL EXPENSES: EFFICIENCY VS COMPATIBILITY
}

\author{
Nevia Čičin-Šain*
}

\begin{abstract}
Summary: Thin-capitalisation rules are rules applied by a number of countries in order to protect their national tax base from erosion by companies that have a relatively high level of debt compared to equity. Indeed, the tax treatment of dividend distributions and interest payments differs significantly and this in return has an effect on the amount of profit a company reports for tax purposes. Country tax rules typically allow a deduction for interest paid or payable in arriving at the tax measure of profit. The higher the level of debt in a company, and thus the amount of interest it pays, the lower its taxable profit will be. For this reason, debt is often a more tax efficient method of finance than equity.
\end{abstract}

In recent years, countries all over the world and even more so the Member States of the European Union and the Organisation for Economic Cooperation and Development (OECD) have been trying to combat the negative effect this difference in taxation has on their economies.

However, Member States of the European Union are bound by EU law and its provisions on the non-discrimination of companies coming from other European Member States.

The focus of this article is Croatian thin-capitalisation rules and their effect. The main hypothesis is that Croatian rules on thin-capitalisation are contrary to EU law. In order to demonstrate this, the author first explains what the rules on thin-capitalisation are and what kind of thin-capitalisation rules exist. Subsequently, the author analyses the relevant provisions of EU law, as well as the case law of the Court of Justice of the European Union regarding thin-capitalisation rules. This analysis is then applied to the existing Croatian rules and finally a conclusion is made as to their potentially discriminatory effect. Finally, the author examines several ways a potentially incompatible thin-capitalisation rule can be made compatible with EU law.

\footnotetext{
Nevia Čičin-Šain, DSc, LLM (Université Paris 1 - Panthéon Sorbonne), senior teaching assistant, Department for Tax Law, Faculty of Law, University of Zagreb.
} 


\section{Introduction}

Companies can finance their activities either with their own or with borrowed capital. There are different theories on the optimal ratio between debt and equity. However, this choice is not at all tax neutral and the way a company is capitalised will often have a significant impact on the amount of profit it reports for tax purposes. In an ideal system of corporate income taxation, the deduction of all interest payments should be allowed since they represent an expense used to generate income. However, abuse of this rule can lead to unwanted consequences. As the Organisation for Economic Cooperation and Development (hereinafter: OECD) explains:

Country tax rules typically allow a deduction for interest paid or payable in arriving at the tax measure of profit. The higher the level of debt in a company, and thus the amount of interest it pays, the lower will be its taxable profit. For this reason, debt is often a more tax efficient method of finance than equity. ${ }^{1}$

Thin capitalisation refers to the situation where a company is financed through a relatively high level of debt compared to equity. This makes the company rather vulnerable in times of financial crises, since the cost of borrowing capital can rise significantly and companies might not even be able to close their financial constructions. Even in periods when there are no financial crises, the fact that a company is thinlycapitalised sends a rather negative signal to the markets.

For a State, overindebtedness can lead to a big loss in tax revenues, without necessarily gaining any economic profits. Moreover, having in mind that financial markets are being globalised, this tax 'advantage' given to national companies can even pour out to other countries. Indeed, in purely domestic situations, thin-capitalisation issues do not even pose a problem since, from the State's perspective, an amount that is being deducted in the hands of one taxpayer is later added to the tax base of the lender and taxed. From a State's perspective, it is entirely irrelevant which company gets taxed. However, the scene changes entirely when the lender is a foreign company.

Even though the Croatian Corporate Income Tax Act (hereinafter: CITA) ${ }^{2}$ does not mention it expressly, the principle of the deductibility of financial charges derives from the general principle according to which the tax base is determined. The corporate tax base in Croatia is the dif-

\footnotetext{
OECD 'Thin Capitalisation Legislation: A Background Paper for Country Tax Administrations' (OECD 2012) 3.

2 Corporate Income Tax Act (Official Gazette 177/04, 90/05, 57/06, 146/08, 80/10, 22/12, 148/13, 143/14) (Croatia).
} 
ference between revenue and expenditure assessed in the profit and loss statement under the accounting rules, which is then increased and reduced by tax-specific items under the corporate tax provisions. Therefore, financial charges, parts of which are interest payments, are expenses that need to be included when calculating the tax base.

However, the legislator decided to limit the deduction of interest payments in some cases. This might seem contradictory to the principle cited above, or contradictory to the fact that current monetary policy encourages indebtedness. Prior to exploring the mechanisms for limiting the deductibility of financial charges, we shall briefly give the reasons why the legislator decided to introduce them.

\section{Different types of thin-capitalisation rules}

Thin-capitalisation rules are rules that aim to stop the erosion of the corporate tax base. The first large studies regarding rules on limiting the deductibility of financial expenses were conducted by the OECD in $1987^{3}$ and by the International Fiscal Association (IFA) in $1994^{4}$ and $1996 .{ }^{5}$ This topic was recently brought up again in the scope of a report on base erosion and profit shifting issued by the OECD 6 and in a Council Directive of 12 July 2016 laying down rules against tax avoidance practices that directly affect the functioning of the internal market. ${ }^{7}$

In order to better understand and analyse the Croatian rules on thin-capitalisation, it could be useful to situate them on the horizon of

\footnotetext{
3 OECD, Thin Capitalization: Taxation of Entertainers, Artistes and Sportsmen (Issues in International Taxation, OECD 1987).

4 IFA Cahiers, 'Deductibility of Interest and Other Financing Charges in Computing Income' (IFA 1994) vol 79a.

5 IFA Cahiers, 'International Aspects of Thin Capitalization' (IFA 1996) vol $81 \mathrm{~b}$.

6 OECD, 'Action Plan on Base Erosion and Profit Shifting' (OECD 2013). In Action 4, headed 'Limit base erosion via interest deductions and other financial payments' it is stated: 'Develop recommendations regarding best practices in the design of rules to prevent base erosion through the use of interest expense, for example through the use of related-party and third-party debt to achieve excessive interest deductions or to finance the production of exempt or deferred income, and other financial payments that are economically equivalent to interest payments. The work will evaluate the effectiveness of different types of limitations. In connection with and in support of the foregoing work, transfer pricing guidance will also be developed regarding the pricing of related party financial transactions, including financial and performance guarantees, derivatives (including internal derivatives used in intra-bank dealings), and captive and other insurance arrangements. The work will be co-ordinated with the work on hybrids and CFC rules'17.

7 Council Directive (EU) 2016/1164 laying down rules against tax avoidance practices that directly affect the functioning of the internal market [2016] OJ L193. The Directive elaborates thin-capitalisation rules in art 4. However, since the aim of this paper is to demonstrate the potential incompatibility of Croatian thin-capitalisation rules with EU law and not to suggest new ones, the author does not go into an in-depth analysis of the thincapitalisation rules proposed in the Directive.
} 
other typical rules regarding thin-capitalisation. Indeed, countries have a vast array of rules destined to curb thin-capitalisation, rules that can be classified into general and specific ones. The first would encompass rules containing the abuse of law principle or the arm's length principle. The others are more specifically tailored to precisely fight thin-capitalisation.

Here again, there are different variations of these rules that can be classified depending on different keys of classification, based on:

a) their material scope of application - rules determining a maximum amount of debt on which deductible interest payments are available and those determining a maximum amount of interest that may be deducted by reference to the ratio of interest (paid or payable) to another variable; ${ }^{8}$

b) their territorial scope of application - rules applicable solely when the lender is situated in a country with low taxation or rules applicable when the lender is a non-resident or rules applicable when the loans are provided by both a resident or non-resident lender;

c) the quality of debt - internal debt (intra-group), external debt, external debt but guaranteed by a dependant person (back-to-back loans).

d) the criterion used for an appreciation of what is to be considered acceptable - a ratio of debt to equity, or a limitation to a percentage of EBITDA, or a limitation according to the arm's length principle;

e) whether, when the ratio is surpassed, the assumption of excessive indebtedness is irrebuttable or rebuttable and, ultimately, having in mind the consequences;

f) whether excessive interest payments are simply non-deductible or whether they are requalified as hidden dividend distributions. ${ }^{9}$

\section{Croatian thin-capitalisation rules}

The Croatian 'arsenal' of measures destined to fight excessive interest deduction consists of the following rules:

1. Rules on penalty interest accumulated between associated persons. Penalty interest is not deductible and it increases the tax base (article 7.1.8 CITA);

2. Rules on interest on loans granted by shareholders or company members (article 8 CITA and article 32 of the Regulation on Corporate Income Tax (hereinafter: Regulation on CIT) ${ }^{10}$ );

$\operatorname{OECD}(\mathrm{n} 1) 7$.

9 H Kruger, Liberté de gestion et endettement des entreprises en droit fiscal (LGDJ 2007) 288.

10 Regulation on Corporate Income Tax (Official Gazette 95/05, 133/07, 156/08, 146/09, 123/10, 137/11, 61/12, 146/12, 160/13, 12/14, 157/14, 137/15) (Croatia). 
3. Rules on interest in transactions between associated persons the application of transfer pricing rules on financial relations (article 14 CITA and article 37 of the Regulation on CIT).

In this paper, we will investigate only measures two and three, because we deem the first measure rather self-explanatory. Indeed, in transactions including related parties, it would be very easy to deliberately stall payments and thus incur penalty interest solely for the purpose of reducing the tax base. Logically, the lawmaker did not allow for such payments to reduce the tax base.

\subsection{Rules determining a maximum amount of debt on which deductible interest payments are available 11}

The application of these rules depends on the fulfilment of two criteria. The first criterion concerns the person of the lender. Namely, the rules apply only if the lender is an associated person who has sufficient participation in the company of the borrower that can provide it with decisive influence over the decision-making process. The legislator fixed this participation to $25 \%$ of shares in the capital or voting rights. The 2013 amendments to the CITA extend this rule to loans received from related persons. Persons are considered related if one person participates directly or indirectly in the management, control or capital of another person, or the same persons participate directly or indirectly in the management, control or capital of the company. Loans given by third persons, but guaranteed by a person having the required participation, are also concerned by these rules.

The second criterion concerns the amount of loan that the lender who satisfies the first criterion needs to lend to the borrower in order to trigger the application of the thin-capitalisation rules. The amount of loan needs to exceed four times the shareholder's share in capital or voting rights.

The fraction of interest payments that are deemed excessive is purely and simply not deductible by the borrowing company and it needs to be reintegrated into its tax base. These rules do not concern the interest on loans borrowed from a financial institution.

Since the 2013 amendments, the rules also apply to loans granted by a non-associated person but guaranteed by an associated person, socalled back-to-back loans, since companies could easily circumvent the application of thin-capitalisation rules by providing financing via a nonassociated person that would be guaranteed by the associated person covered by the rules.

$\overline{11}$ Art 8 CITA (n 2) and art 32 Regulation on CIT (n 10). 
The Regulation on Corporate Income Tax provides that if the interest payments are taxable in the hands of the lender by Croatian personal or corporate income tax, the deduction of these interest payments from the borrower's point of view is permissible. This is also a logical solution, for if it were not permissible the same amount of interest would be taxed twice - first via non-deducting the interest payments in the hands of the borrower and secondly by taxing them in the hands of the lender.

If we were to analyse the Croatian rules in view of the classifications noted above, we could conclude that they belong to the rules whose territorial application is limited solely to non-residents regardless of whether they are resident in a high or a low tax jurisdiction. The rules apply mostly to internal debts (intra-group) and to external ones insofar as these loans are guaranteed by an associated person. The criterion used to determine what constitutes an admissible amount of debt is an irrebuttable ratio of debt to equity. Finally, the Croatian CITA stipulates that interest payments are simply deemed non-deductible and are therefore not requalified as hidden dividend distributions.

\subsection{Rules determining a maximum amount of interest that may be deducted by reference to another interest rate 12}

As was stated previously, Croatian law not only limits the deductibility of interest payments linking them to the amount of the debt granted, but also by limiting the interest rate.

Therefore, to determine income from interest on loans granted by associated persons, the minimum calculated interest rate is the rate which would apply to non-associated persons at the time of granting a loan. However, to determine expenditures for interest on loans received by associated persons, the maximum interest accrued is recognised at the interest rate which would apply to non-associated persons at the time of granting a loan. The interest rate referred to in those two paragraphs of article 14 CITA are determined and published by the finance minister, prior to the beginning of the tax period in which it is applied, taking into account that this interest rate is realised under comparable circumstances or would be realised in transactions between non-associated persons. If the minister fails to publish such an interest rate, the discount rate of the Croatian National Bank published in the Official Gazette will be applicable. These rules also apply to resident associated persons if one of the persons: 1 . has a privileged tax status or is subject to profit tax at a rate lower than the stipulated rates or is exempt from the payment of profit tax; or 2. is entitled to carry forward the tax loss from previous tax periods.

12 Art 14 CITA (n 2) and art 37 of the Regulation on CIT (n 10). 
As stated above, these rules are actually rules on transfer pricing applied to financial relations. The position of these rules, immediately after article 13 CITA (transfer pricing rules), also indicates that article 14 can be considered as an extension of the transfer pricing rules to financial relations. Even though transfer pricing is not the main topic of this paper, the author deems it necessary to briefly explain this notion, as well as the arm's length principle. Transfer prices are prices applied between associated enterprises. The arm's length principle simply states that transactions between associated enterprises should not be distorted by the special relationship that exists between the parties. As such, the arm's length principle is neutral. ${ }^{13}$

\section{Compatibility with EU law}

In this part of the paper we will put the compatibility of Croatian thincapitalisation rules with EU law to the test. However, it is necessary first to explain that there is no explicit provision for legislative competences in the area of direct taxation in the EU Treaty. The legislation that exists on the taxation of companies has usually been based on article 115 of the Treaty on the functioning of the European Union (hereinafter: TFEU), which authorises the Union to adopt directives on the approximation of such laws, regulations or administrative provisions of the Member States that directly affect the establishment or functioning of the internal market. However, these require unanimity and the application of the consultation procedure, resulting in very sparse legislation in the field.

This does not mean that national lawmakers can legislate in the area of direct taxation without taking into consideration the boundaries set by EU law. This is the consequence of the so-called negative integration process. As opposed to positive integration - integration through positive action (coordination, common policy-making, approximation of national laws or even unification) - negative integration is integration through legally enforceable prohibitions of certain measures of Member States which violate the basis of a common market, such as cartel agreements and other distortions of competition and discriminatory, restrictive or protective government measures. The correlation between positive and negative integration can be explained as follows:

... as long as no positive integration has been achieved in a certain matter, such as direct taxation, Member States remain in principle free to regulate that matter as they consider appropriate, except for matters exclusively attributed to the EC to be regulated, such as the common trade, agricultural and fisheries

13 OECD, Transfer Pricing Legislation: A Suggested Approach (OECD 2011) 3. 
policies. But this national sovereignty is restricted by negative integration, i.e. by the EC Treaty prohibitions, especially the free movement rules and the competition rules of which the ban on State aid to undertakings is the most important one in the field of taxation. ${ }^{14}$

In the Schumacker case, the Court of Justice of the European Union (hereinafter: CJEU) said: 'Although, as Community law stands at present, direct taxation does not as such fall within the purview of the Community, the powers retained by the Member States must nevertheless be exercised consistently with Community law'. ${ }^{15}$ This means that the exercise of the national competences in the field of tax law is subject to boundaries that EU law imposes and which are related to the existence of articles on free movement (articles 28 - 37 and $45-66$ TFEU).

According to Union law, tax advantages need to be granted ensuring equal treatment. However, for this principle of equal treatment to apply, two situations need to be comparable. When talking about the notion of discrimination, the Court determines it in the following manner: 'It is also settled law that discrimination can arise only through the application of different rules to comparable situations or the application of the same rule to different situations'. ${ }^{16}$ Discrimination can have two forms - direct discrimination - based on nationality, ${ }^{17}$ and indirect discrimination - all forms of discrimination which, by the application of other criteria of differentiation, lead in fact to the same result. ${ }^{18}$

In the case of companies, nationality is determined based on the location of the company's seat. ${ }^{19}$ For instance, in the cases Royal Bank of Scotland $(R B S)^{20}$ and Commission $v$ France, ${ }^{21}$ national tax measures were

\footnotetext{
14 BJM Terra and PJ Wattel, European Tax Law (4 ${ }^{\text {th }}$ edn, Kluwer International Law 2005) 28.

15 Case C-279/93 Finanzamt Köln-Altstadt v Roland Schumacker [1995] ECR I-00225, para 21.

16 Case C-279/93 Finanzamt Köln-Altstadt v Roland Schumacker [1995] ECR I-00225, para 30; Case C-80/94 GHEJ Wielockx $v$ Inspecteur der Directe Belastingen [1995] ECR I-02493 para 17; and Case C-107/94 PH Asscher v Staatssecretaris van Financiën [1996] ECR I-03089, para 40.

17 Case C-270/83 Commission of the European Communities v French Republic [1986] ECR 00273. For a comment, see T O'Shea, 'Freedom of Establishment Tax Jurisprudence: Avoir Fiscal Re-visited' (2008) 17(6) EC Tax Review 259. Also see Case C-311/97 Royal Bank of Scotland [1999] ECR I-02651.

18 M Dahlberg, Direct Taxation in Relation to the Freedom of Establishment and the Free Movement of Capital (Kluwer Law 2005) 67.

19 Case C-1/93 Halliburton Services BV v Staatssecretaris van Finances [1994] ECR I-1137, para 20.

20 Case C-311/97 Royal Bank of Scotland plc v Elliniko Dimosio [1999] ECR I-2651.

21 Case C-270/83 Commission v France [1986] ECR 273.
} 
found to be in breach of article 49. They were discriminatory because the tax advantage was granted to companies only if they had their registered seat in the State granting the tax advantage. However, here there is a difference between countries applying the so-called siège réel doctrine, according to which a company has its residence in the country in which it has a real economic establishment and is not just being incorporated 'on paper'. In a country which applies this doctrine, measures which make a difference based on residency, which does not necessarily coincide with the place of incorporation, are deemed to be indirectly discriminatory and can therefore be justified not only based on the express derogations found in article 52, but also based on objective justifications. On the other hand, discriminatory measures in countries in which residency is determined by the place of their incorporation are deemed to be directly discriminatory and can thus be justified solely by one of the express derogations (the RBS case).

To avoid some of the problems arising from the RBS line of case law, the Court has tended to use the formula based on removing hindrances, obstacles or restrictions to the freedom of establishment which can be justified by more appropriate justifications. ${ }^{22}$

That being said, there is ongoing concern about the inherent tension between the 'restriction' approach and the taxation regimes in Member States which differ significantly in respect of tax rates, tax bases and accounting rules. Indeed the sole fact that a Member State has higher tax rates than another Member State makes it less attractive for a foreign company to establish itself in that particular State. ${ }^{23}$

On the other hand, taxation systems are inherently discriminatory. For instance, both international tax law and Union law recognise the principle of territoriality, namely that resident companies are taxed on their worldwide profits, while non-resident companies are taxed only on profits arising from sources located in that taxing state (limited taxation).

So, the question remains how to reconcile these opposing principles? In an opinion in the ACT Group Litigation, ${ }^{24}$ Advocate General Geelhoed offered a potential solution. He suggested a distinction between 'quasirestrictions' and 'true restrictions'. The first ones are those that result inevitably from the coexistence of national tax systems because of: 1) the existence of parallel administrative compliance burdens; 2) the disparities between national tax systems; and 3) the necessity to divide tax juris-

\footnotetext{
${ }^{22}$ M Gammie, The Role of the European Court of Justice in the Development of Direct Discrimination in the European Union' (2003) 57 Bulletin for International Fiscal Documentation 86.

${ }^{23}$ C Barnard, The Substantive Law of the EU (3 $3^{\text {rd }}$ edn, OUP 2010) 336 and 337.

24 Case C-374/04 ACT Group Litigation [2007] ECR I-11673.
} 
dictions. If the different treatment of the comparator companies is based on the internationally accepted distinction in tax law between residents and non-residents, then the matter should fall outside the Treaty prohibition on discrimination. Indeed, these restrictions can sometimes provide companies with advantages. The other restrictions go beyond what is the inevitable consequence of the coexistence of national tax systems. He considers that because the criteria determining direct tax jurisdiction are residence or source-based, this means that the truly restrictive national direct tax measures will in practice qualify as directly or indirectly discriminatory measures and that true restrictions should be analysed solely under the discrimination approach. In his opinion, if a rule is truly non-discriminatory, it will not breach the Treaties. ${ }^{25}$

One can conclude from the discussion above that this is a very complex debate that has not produced a straightforward answer. National thin-capitalisation measures might potentially discriminate against other companies that are not nationals of the Member State in question since they often come into play only when the lending company is situated in another country. Therefore, in order to investigate whether there is potential incompatibility with EU law, the case law of the Court in the matter of thin-capitalisation rules needs to be analysed.

\section{1 Applicable freedom}

Let us recall that the Treaty on the Functioning of the European Union provides for the following freedoms: free movement of goods (articles 28 - 37), free movement of workers (articles $45-48$ ), the right of establishment (articles 49 - 55), freedom to provide services (articles 56 - 62), and free movement of capital (article 63 - 66). The two freedoms that are relevant for the matter at hand are the right of establishment ${ }^{26}$ and the free movement of capital. ${ }^{27}$

\footnotetext{
25 Barnard (n 23) 339 and 340.

26 Article 49 TFEU reads as follows: 'Within the framework of the provisions set out below, restrictions on the freedom of establishment of nationals of a Member State in the territory of another Member State shall be prohibited. Such prohibition shall also apply to restrictions on the setting-up of agencies, branches or subsidiaries by nationals of any Member State established in the territory of any Member State. Freedom of establishment shall include the right to take up and pursue activities as self-employed persons and to set up and manage undertakings, in particular companies or firms within the meaning of the second paragraph of Article 54, under the conditions laid down for its own nationals by the law of the country where such establishment is effected, subject to the provisions of the Chapter relating to capital'.

27 Article 63 TFEU reads as follows: ' 1 . Within the framework of the provisions set out in this Chapter, all restrictions on the movement of capital between Member States and between Member States and third countries shall be prohibited. 2. Within the framework of the provisions set out in this Chapter, all restrictions on payments between Member States and between Member States and third countries shall be prohibited'.
} 
In order to determine which freedom is applicable, it is necessary to establish their respective scopes of application, as determined by the TFEU and the relevant case law of the CJEU. For example in the Baars case, the Court concluded that:

It is clear from the second paragraph of Article 52 of the Treaty that freedom of establishment includes the right to set up and manage undertakings, in particular companies or firms, in a Member State by a national of another Member State. So, a national of a Member State who has a holding in the capital of a company established in another Member State which gives him definite influence over the company's decisions and allows him to determine its activities is exercising his right of establishment. ${ }^{28}$

Therefore, a person possessing a holding giving him a definite influence over the company's decisions and allowing him to determine its activities is exercising his right of establishment.

On the other hand, the Court defined the free movement of capital in the following manner:

Although the Treaty does not define the terms 'movements of capital' and 'payments', it is settled case-law that Directive 88/361, together with the nomenclature annexed to it, has an indicative value for the purposes of defining the notion of capital movements (see Commission v United Kingdom, paragraph 39, and Case C-222/97 Trümmer and Mayer [1999] ECR 1-1661, paragraphs 20 and 21). Points I and III of the nomenclature annexed to Directive 88/361 and the explanatory notes which it contains indicate that direct investment in the form of a shareholding in an undertaking and the acquisition of securities on the capital market constitute capital movements within the meaning of Article 56 EC. By virtue of those explanatory notes, direct investment, in particular, is characterised by the possibility of participating effectively in the management and control of a company. ${ }^{29}$

Since the TFEU does not establish how the freedoms should interact if a national rule infringes both at the same time, it was up to the Court of Justice to decide which freedom is applicable. The Court adopted two

28 Case C-251/98 C Baars v Inspecteur der Belastingen Particulieren/Ondernemingen Gorinchem [2000] ECR I-02787, para 22. For comments on the case, see A Lupo, 'Reliefs from Economic Double Taxation on EU Dividends: Impact of the Baars and Verkooijen Cases' (2000) 40(7) European Taxation 270.

29 Case C- 174/04 Commission of the European Communities v Italian Republic [2005] ECR I-04933, para 27. 
approaches: a priority approach ${ }^{30}$ - an approach according to which the free movement of capital should be analysed only if the free movement of capital does not apply, and the parallel approach - according to which both freedoms should apply concomitantly. ${ }^{31}$

Which approach prevails is not perfectly clear, either from the case law, or from the legal doctrine. However, and without going into the details of this rather extensive debate which would go beyond the scope of this paper, we will quote Professor Lang who says that:

To summarize, it can be said that the Court has developed a new rule of priority. Whenever the discriminatory effects of a national provision are within the scope of two fundamental freedoms and one of them is predominantly affected, the other one is only affected as an 'unavoidable consequence' and consequently does not apply. In recent case law, the Court confirmed this new concept and emphasized that the purpose of the respective legislation is decisive. ${ }^{32}$

The question of which fundamental freedom is applicable is not irrelevant. Indeed, free movement of capital applies also to relations with third countries, contrary to the other freedoms, including the right of establishment. Thus, the determination of the correct freedom is indispensable for the judgement of the compatibility of national thin-capitalisation rules with EU law. We will now look specifically into the relevant case law regarding national thin-capitalisation rules and their compatibility with EU law.

\subsection{European cases regarding national thin-capitalisation rules}

There is a relatively substantial body of case law concerning thin-capitalisation rules. The first case was Langhorst-Hohorst. ${ }^{33}$ This case is highly relevant for our study since Croatian thin-capitalisation rules are fairly similar to the old German rules on thin-capitalisation that were tested by the CJEU. Article 8A of the Körperschaftsteuergesetz (German corporate income tax), in its version applicable from 1996 to 1998, reads as follows:

\footnotetext{
30 Case C-436/00 $X$ and $Y$ [2002] ECR I-10829, paras 66-68.

31 Case C-157/05 Holböck [2007] ECR I-04051, paras 27-31. For a comment of this case, see S Hindelang, The Free Movement of Capital and Foreign Direct Investment: The Scope of Protection in EU Law (OUP, 2009) 106 and 107.

32 M Lang, Introduction to European Tax Law: Direct Taxation (Spiramus Press Ltd 2013) 107.

33 Case C-324/00 Lankhorst-Hohorst GmbH v Finanzamt Steinfurt [2002] ECR I-11779. See H Arbutina, 'Potkapitaliziranje kao metoda izbjegavanja obveze poreza na dobit' (2010) Zbornik radova s međunarodne znanstvene konferencije 'Financiranje, upravljanje i restrukturiranje trgovačkih društava u doba recesije' 239.
} 
Repayments in respect of loan capital which a company limited by shares subject to unlimited taxation has obtained from a shareholder not entitled to corporation tax credit which had a substantial holding in its share or nominal capital at any point in the financial year shall be regarded as a covert distribution of profits,

$\cdots$

2. where repayment calculated as a fraction of the capital is agreed and the loan capital is more than three times the shareholder's proportional equity capital at any point in the financial year, save where the company limited by shares could have obtained the loan capital from a third party under otherwise similar circumstances or the loan capital constitutes borrowing to finance normal banking transactions..... ${ }^{34}$

In this case, the Court declared the German regime contrary to EU law because it constituted a difference in treatment between resident subsidiary companies according to the seat of their parent company. The Court considered this to be an obstacle to the freedom of establishment which is, in principle, prohibited by Article 43 EC. The tax measure in question in the main proceedings makes it less attractive for companies established in other Member States to exercise freedom of establishment and they may, in consequence, refrain from acquiring, creating or maintaining a subsidiary in the State which adopts that measure (para 32).

The Court rejected the arguments proposed by the Government that the discrimination is justifiable because it was necessary to combat tax evasion or ensure the coherence of the applicable tax systems (paras 39 -42) or to ensure the effectiveness of fiscal supervision (paras 43 - 45).

The Langhorst-Hohorst case had a profound impact on thin-capitalisation rules all over the European Union. Following this judgment, a number of companies in the United Kingdom decided to demand restitution or compensation for the non-deductibility of interest paid by British companies to other companies of the same group that were not resident in the UK, but rather in another Member State. Thus, the Court was asked to assess once again the compatibility of thin-capitalisation rules with EU law, this time in the case of British rules. ${ }^{35}$

\footnotetext{
34 Kruger (n 9) 355.

35 Case C-524/04 Test Claimants in the Thin Cap Group Litigation v Commissioners of Inland Revenue [2007] ECR I-02107 (Thin-Cap GLO). For comments on the case, see M Gammie, 'Pending Cases Filed by UK Courts II: The ACT, FII, and Thin Cap Group Litigations and the Marks \& Spencer Case' in M Lang (ed), ECJ: Recent Developments in Direct Taxation (Linde 2006) 323; FF Vandoren, 'La Cour de justice européenne se prononce sur les règles
} 
The test cases involved, first, loans granted to a UK-resident company by a company established in another Member State, and each of the companies belonging to the same group of companies, the ultimate parent company of which was also established in that other State. This applied to some of those test cases, namely those involving the Lafarge and Volvo groups, in which the lending company and the parent company were established in the same Member State, that is to say, in those cases, France and Sweden respectively. Other test cases involved a UKresident company which belonged to a group of companies headed by a parent company established in a non-member country, namely the United States of America or in another Member State but operating through a branch resident in a non-member country.

The Court held that the British legislation which was targeted only at relations within a group of companies primarily affected the freedom of establishment and should, accordingly, be investigated in the light of article $43 \mathrm{EC}$. This is because the national rules applied to UK-resident subsidiaries which were at least $75 \%$ owned, directly or indirectly, by a non-resident parent company or by another non-resident company which was also at least $75 \%$ owned, directly or indirectly, by that parent company, which of course granted them a definitive influence over the decision-making process of the subsidiary.

However, contrary to the decision the Court reached in the Lankhorst-Hohorst case, in Thin-Cap GLO the Court said that a piece of legislation of a Member State may be justified by the need to combat abusive practices where it provides that interest paid by a resident subsidiary to a non-resident parent company is to be treated as a distribution only if, and in so far as, it exceeds what those companies would have agreed upon on an arm's length basis, that is, the commercial terms which those parties would have accepted if they had not formed part of the same group of companies. In the Lankhorst-Hohorst case, that requirement was not met by national legislation which did not have the specific purpose of preventing wholly artificial arrangements designed to circumvent that legislation, but applied generally to any situation in which the parent company had its seat, for whatever reason, in another Member State (para 37).

A piece of national legislation can be regarded as proportional if the taxpayer is given an opportunity, without being subject to undue administrative constraints, to provide evidence of any commercial justification that there may have been for that arrangement and in the second place,

de la "sous capitalisation" en Grande Bretagne' (Fiscalité européenne 2007) no 149, 3; F Perrotin, 'Un élargissement inattendu de la notion communautaire d'abus de droit' (Petites affiches / La Loi / Le Quotidien juridique 2007) vol 66, 3; H Kruger, 'Non-conformité d'une législation restreignant la faculté de déduire les intérêts versés à une société mère non résidente' (Revue de droit fiscal 2007) no 764, 45. 
that, where the consideration of those elements leads to the conclusion that the transaction in question represents a purely artificial arrangement without any underlying commercial justification, the re-characterisation of interest paid as a distribution is limited to the proportion of that interest which exceeds what would have been agreed had the relationship between the parties or between those parties and a third party been one at arm's length (paras 82 et 83).

In this context, it is for the national court to determine whether that regime gave them an opportunity to provide evidence as to any commercial justification there may have been for the transactions, without being subject to any undue administrative constraints.

Having said that, it is necessary to underline that the British legislation differed from the German one contested in Lankhorst-Hohorst in many aspects. Without entering into details, it is sufficient to say that the British rules did not make a reference to a fixed ratio, but rather to an 'economically reasonable' criterion.

The third case, Lasertec, ${ }^{36}$ referred also to the German thin-cap rules. The Court gave its decision by way of a reasoned order, because it qualified that the reply to the question posed to the Court can be deduced from existing case law. The question that the national court posed was whether national rules, in accordance with which the loan interest paid by a resident capital company to a shareholder established in a non-member country who has a substantial holding in the capital of that company is, under certain conditions, regarded as a covert distribution of profits which is taxable in the hands of the resident borrowing company, are compatible with the provisions of the EC Treaty relating to the free movement of capital. In order to explain which freedom was indeed applicable, the Court affirmed that: it is apparent from settled case-law that in order to ascertain whether national legislation falls within one or the other of the freedoms of movement, the purpose of the legislation at issue must be taken into consideration' (para 19). The rules stipulated that: 'A significant holding exists where the shareholder holds directly or indirectly - also through a partnership - over one quarter of the share or nominal capital of the company limited by shares' (para 4). For this paper, one needs to remark that this is the same percentage required by the Croatian legislation.

The Court went on:

The treatment of a lesser holding which nevertheless confers a dominant influence over the company concerned as such a hold-

36 Case C-492/04 Lasertec Gesellschaft für Stanzformen mbH v Finanzamt Emmendingen [2007] ECR I-3775. 
ing shows, as stated by the Commission in its written observations, that, for the German legislature, the national measure at issue in the main proceedings is designed to apply, irrespective of a precise threshold, to holdings giving the holder a definite influence on the decisions of the company concerned and allowing him to determine its activities, in accordance with the case-law noted in paragraph 20 above ... (para 22).

The Court then followed with the conclusion that:

... this case falls within the material scope solely of the Treaty provisions relating to freedom of establishment (para 24)... As for the chapter of the Treaty relating to freedom of establishment, it does not include any provision which extends the scope of its provisions to situations involving nationals of non-member countries who are established outside the European Union (para 27).

In the NV Lammers and Van Cleeff case, ${ }^{37}$ the facts were the following: the Belgian subsidiary was created on 25 July 1991. The nominated directors were the two shareholders of the Belgian subsidiary as well as the parent company Lammers \& Van Cleeff BV, located in the Netherlands. The subsidiary paid interest to the parent company Lammers \& Van Cleeff BV for a loan that it received from the parent company. However, the national legislation provided for a different treatment of interest payments paid to a company which acted as a director, dependant on whether or not this company had its residence in Belgium. Indeed, the legislation at hand did not provide for a recharacterisation of interest into dividends when the lender was a resident company, even if one of the two limits posed in article 18, first paragraph, $3^{\circ}$, of CIR (Code des revenues 1992) was met. On the other hand, if the interest payments were made to a non-resident company, the limits were applicable and the payment would be requalified into dividends and taxed accordingly. Therefore, companies directed by a non-resident company were treated less favourably.

Once again, the Court reiterated that a difference in treatment between companies based on the residence of the company acting as the administrator and providing the loan constitutes a restriction of the freedom of establishment. Since the provisions regarding the freedom of establishment oppose the application of such a national legal provision, there was no need to further investigate whether the free movement of capital was also applicable.

37 Case C-492/04 Lammers \& Van Cleeff NV v Belgische Staat ECR [2008] I-00173. 
It has not been until very recently that the Court sanctioned for the first time thin-capitalisation rules because they infringed the free movement of capital. This happened in the case Itelcar-Automóveis de Aluguer Lda. ${ }^{38}$ Here, the Portuguese company Itelcar received a loan from an associated company GE Capital, resident in the USA.

The Portuguese rules provided that if the amount of the loan surpasses twice the amount of the borrower's participation in the company's capital, the interest linked to that part of the loan is not to be treated as deductible (paras $1-3$ ).

The Portuguese rules allowed the taxpayer to prove that it would have been possible to obtain such a loan from a third independent party. Itelcar was in the position of having an excessive debt in the fiscal years 2004 - 2007 and it was not able to prove that it could get the same amount of debt from an independent entity. It also could not prove that the difference in the interest rate was respecting the arm's length principle.

The referring court asked whether the national legislation was not opposing article 63 TFEU (TEC 56) and article 65 TFEU (TEC 58), in other words the free movement of capital. Once again, until this case, the Court had never assessed the rules in the light of the free movement of capital, but rather the freedom of establishment. When deliberating on which freedom was applicable, the Court stated that, in relation to national legislation on the tax treatment of dividends originating in a non-member country, it is sufficient to examine the purpose of that legislation in order to determine whether the tax treatment falls within the scope of the Treaty provisions on the free movement of capital. Since the Treaty chapter on freedom of establishment does not contain any provision which extends the application of its provisions to situations concerning the establishment of a company of a Member State in a non-member country or the establishment of a company of a non-member country in a Member State, such legislation cannot fall within the scope of article 43 EC (para 16). The Court has also held that, where it is apparent from the purpose of such national legislation that it can apply only to those shareholdings which enable the holder to exert a definite influence on the decisions of the company concerned and to determine its activities, neither article 43 EC nor article 56 EC may be relied upon (para 17).

On the other hand, national rules relating to the tax treatment of dividends coming from a non-member country which do not apply exclusively to situations in which the parent company exerts decisive influence over the company paying the dividends must be assessed in the light of

38 CaseC-282/12 Itelcar-Automóveis de AluguerLdavFazendaPúblicaECLI:EU:C:2013:629. 
article 56 EC. A company resident in a Member State may therefore rely on that provision in order to call into question the legality of such rules, irrespective of the size of its shareholding in the company paying dividends established in a non-member country (para 18).

Since the national legislation at issue in the main proceedings did not relate only to situations in which the lending company of a non-member country exerts a definite influence over the resident borrowing company by reason of its shareholding in that company, a resident company may, irrespective of whether the lending company of the non-member country has a shareholding in it, or of the size of any such shareholding, rely upon the Treaty provisions on the free movement of capital in order to call into question the legality of such national rules (paras $19-23$ ). ${ }^{39}$

Concerning potential justifications of such a restriction, the Court concluded that it should be recalled that, according to settled case law, a national measure restricting the free movement of capital may be justified where it specifically targets wholly artificial arrangements which do not reflect economic reality and the sole purpose of which is to avoid the tax normally payable on the profits generated by activities carried out on the national territory (para 34).

By providing that certain interest paid by a resident company to a company established in a non-member country, with which it has special relations, is not to be deductible for the purposes of determining the taxable profit of that resident company, rules such as those at issue in the main proceedings are capable of preventing practices whose sole purpose is to avoid the tax that would normally be payable on profits generated by activities undertaken in the national territory. It follows that such rules are an appropriate means of attaining the objective of combating tax evasion and avoidance.

Even though the Court accepted the justification, it deemed that the rules at hand went beyond what was necessary to attain the objective. The reason for this was that the term 'special relations', as defined in article 58(4) of the Portuguese Corporation Tax Code (Código do Imposto sobre o Rendimento das Pessoas Colectivas; hereinafter: CIRC), encompasses situations that do not necessarily involve the lending company of a non-member country holding shares in the resident borrowing company. Where there is no such shareholding, the effect of the method for calculating the excess indebtedness laid down in article 61(3) CIRC is that any credit arrangement between those two companies falls to be regarded as excessive (paras 35 and 41).

\footnotetext{
39 In particular, the situations listed in art 58(4)(g) CIRC, which relate to the commercial, financial, business or legal relationships between the companies in question, do not necessarily involve the lending company holding shares in the borrowing company.
} 


\section{Assessing the compatibility of the Croatian thin-capitalisation rules with EU law}

After having depicted the horizon of the settled case law of the Court of the European Union, we shall now assess the compatibility of the Croatian legislation in view of what has been said.

As stated above, the Croatian Regulation on Corporate Income Tax prescribes that if the interest payments that are treated as non-deductible are taxed in the hands of the lender with the Croatian personal or corporate income tax, deduction of these interest payments in the hands of the borrower will then be allowed (paragraphs 5 and 6 of article 32). In other words, if the lender is a Croatian resident, subject to Croatian personal or corporate income tax, the borrowing company will be allowed to deduct the interest that was initially deemed excessive, according to article 8 CITA.

On the other hand, if the lending company is a non-resident company, the interest cannot be considered as deductible in the hands of the borrower. This way of taxation is coherent with the aim of thin-capitalisation rules, which is to prevent the erosion of the Croatian tax base towards foreign countries. Indeed, this would occur if Croatia allowed the deduction of excessive interest payments that would then subsequently be taxed in a foreign country (the country where the lending company is resident).

However, this provision seems to introduce a different treatment of interest payments made to parent companies based on whether the latter have Croatian or foreign residency. Indeed, only Croatian parent companies can be subject to Croatian tax, as opposed to non-resident parent companies that are not.

This kind of difference in treatment between Croatian subsidiaries based on whether they have resident or non-resident parent companies creates a restriction to the freedom of establishment, in principle prohibited by article 49 TFEU (ex article 43 TEC). The Croatian provision renders less attractive the exercise of this fundamental freedom by nonresident companies which can then as a consequence choose to establish themselves elsewhere.

According to the settled case law of the Court of Justice, although direct taxation falls within their competence, Member States must nonetheless exercise that competence consistently with Community law and, in particular, avoid any discrimination on grounds of nationality (Langhorst-Hohorst, para 26), which is precisely the case with the present Croatian rules.

It is the opinion of the author that the Court would not be convinced by justifications based on the risk of tax evasion because the legislation 
at issue should have the specific purpose to prevent wholly artificial arrangements designed to circumvent the national legislation and not apply to any situation in which the parent company has its seat, for whatever reason, outside Croatia. Such situations do not in themselves entail a risk of tax evasion, since such a company will in any event be subject to the tax legislation of the State in which it is established (LanghorstHohorst, para 37).

It follows that the Croatian thin-capitalisation regime, as it is conceived today, is not compatible with EU law and that Croatia risks being sanctioned if the measure is contested before the Court of Justice.

\section{Rendering the Croatian legislation compatible with EU law}

In order to see how the Croatian legislation could be rendered compatible with EU law, the author proposes to conduct a survey of the reactions of other EU lawmakers following the Lankhorst-Hohorst case. ${ }^{40}$

The Netherlands, ${ }^{41}$ Denmark, France ${ }^{42}$ and Germany ${ }^{43}$ chose to apply thin-capitalisation rules to resident taxpayers, as well as non-resident ones. Spain (until 2012) and Portugal chose to take a different route. They restricted the application of these rules solely to situations where the lender was a resident in a third (non-EU) country. Finally, Great Britain chose to entirely eliminate thin-capitalisation rules and to apply rules on transfer pricing, i.e. the arm's length principle, also on financial relations between associated enterprises.

Which of these solutions would best suit Croatian law? If the main aim is to preserve to the maximum the Croatian tax base, whilst rendering the legal norm compatible with EU law, the best option would be to

\footnotetext{
40 B Terra and P Wattel, European Tax Law (5th edn, Kluwer Law International 2008) 585.

41 The Netherlands chose to do it even prior to the Lankhorst-Hohorst case, following the Bosal Holding case, Case C-168/01 Bosal Holding BV contre Staatssecretaris van Financiën [2003] ECR I-09409.

42 The provisions of the new article 212 II of the French General Tax Act - Code général des impôts (CGI) apply to all companies and organisms which are subject to corporate income tax by law or upon option.

43 This was the solution adopted by the German legislator. First, the rules against thincapitalisation were modified in the sense that they covered national and cross-border situations. According to the modified article 8A of the German Körperschaftsteuergesetz, all interest payments above EUR 250,000 paid out to shareholders having more than $25 \%$ of the capital or voting rights were reclassified as dividends if the ratio of debt to equity was above 1.5:1. However, dividend payments made to resident parent companies were $95 \%$ tax exempt, as opposed to dividends paid to non-resident parent companies which were taxed at $25 \%$ withholding tax. In this sense, the new rule still had a discriminatory effect. In 2008 , the German legislator made a drastic turn and replaced the entire rules with a completely new type of rules, called interest barrier rules (Zinsschränke). N Soshnikov, 'Structure and Elements of National Thin Capitalization Rules' in C Massoner, A Storck and B Sturzlinger (eds), International Group Financing and Taxes (Linde Verlag 2012) 61.
} 
simply exclude the application of Croatian thin-capitalisation rules in relation to companies that are resident in the European Union.

Let us first examine this option. Some scholars, notably Rita de la Feria, consider that the decision brought in the Langhorst-Hohorst case left the given countries with the aforementioned three options - to extend the application of thin-capitalisation rules to purely national situations; to exclude their application in relations with companies resident in the European Union; or to simply abolish the rules entirely. However, Rita de la Feria considers that the Itelcar case removed the second possibility for the Member States:

It is now clear that the route followed by Portugal and Spain is regarded as incompatible with EU law. EU member states only have two options: either to extend the scope of application of thin capitalization rules in order to include resident companies; or abolish the rules. Applying them only to non-EU countries is no longer acceptable. ${ }^{44}$

It seems to us that this statement needs to be nuanced, or at least regarded in the context and light of the structure of the Portuguese rules on thin-capitalisation. Let us recall that these rules were tested against the free movement of capital and that the reason the Court decided that the rules were incompatible with EU law was that the Portuguese rules did not apply solely to situations in which the lending company from another Member State had a decisive participation in the borrowing company. Since this particular freedom applies also in relation to third countries, it was obvious that the Portuguese rules were no longer compatible with EU law.

On the other hand, the Lasertec case tells us that, in order to determine which freedom takes precedence, it is necessary to take into consideration the objective of the legislation at hand (para 19). ${ }^{45}$ In the concrete case, German law defined that the national thin- capitalisation rule was applicable to circumstances in which the non-resident lending company has a substantial holding, directly or indirectly, in the nominal capital of the resident borrowing company, namely a holding of over $25 \%$. This is also the case in Croatian law.

\footnotetext{
44 R de la Feria, cited in an article by R Jackson, 'Application of Portugal's Former Thin Cap Rules to Only Third Countries Violated EU Law, ECJ Says' (Tax Analysts, 8 October 2013). 45 'The treatment of a lesser holding which nevertheless confers a dominant influence over the company concerned as such a holding shows, as stated by the Commission in its written observations, that, for the German legislature, the national measure at issue in the main proceedings is designed to apply, irrespective of a precise threshold, to holdings giving the holder a definite influence on the decisions of the company concerned and allowing him to determine its activities, in accordance with the case-law noted in paragraph 20 above ...' (para 22).
} 
The Court concluded that:

[T]his case falls within the material scope solely of the Treaty provisions relating to freedom of establishment (para 24)

As for the chapter of the Treaty relating to freedom of establishment, it does not include any provision which extends the scope of its provisions to situations involving nationals of non-member countries who are established outside the European Union... (para 27).

It follows that national thin-capitalisation rules which apply only when the lending company has a decisive influence in the borrowing company need to be tested exclusively in the light of the freedom of establishment. The Croatian rules also require a decisive participation of at least $25 \%$ in the capital or voting rights of the borrowing company and thus one can argue that these rules can be regarded solely in the light of the freedom of establishment and not the free movement of capital.

Having said that, it remains unclear whether the fact that the Croatian law was amended in 2013 , by extending the thin-capitalisation rules to loans given out by related persons, or loans that are given by third persons, but guaranteed by the persons having the required participation, changes the outcome. Let us recall that persons are considered related if one person participates directly or indirectly in the management, control or capital of another person, or the same persons participate directly or indirectly in the management, control or capital of the company. One could argue that not all these cases require a decisive participation, or substantive shareholding. On the other hand, one could also argue that these requirements are set in order to combat situations in which a person having a decisive participation is using other entities over which it has an influence to circumvent the application of thin-capitalisation rules.

The Itelcar case does not seem to give a straight answer to this question, since the Court investigated the terms of the legislation in the following manner:

So far as concerns the rules at issue in the main proceedings, the term 'special relations', as defined in Article 58(4) of the CIRC, does not - as Itelcar and the European Commission observe relate only to situations in which the lending company of a nonmember country exerts a definite influence, within the meaning of the abovementioned case-law of the Court, over the resident borrowing company by reason of its shareholding in that company. In particular, the situations listed in Article 58(4)(g) of the 
CIRC, which relate to the commercial, financial, business or legal relationships between the companies in question, do not necessarily involve the lending company holding shares in the borrowing company (para 20).

At the hearing, the Portuguese government stated, however, in reply to a question put by the Court, that the rules apply only to situations in which the lending company has a direct or indirect shareholding in the borrowing company.

The Court then stated:

Nevertheless, even if the application of the rules at issue in the main proceedings is confined to situations concerning dealings between a borrowing company and a lending company holding at least $10 \%$ of the shares or voting rights in the borrowing company, or between companies in which the same shareholders have such a holding, as contemplated in Article 58(4)(a) and (b) of the CIRC, it is clear that a holding of such a size does not necessarily imply that the holder exerts a definite influence over the decisions of the company of which it is a shareholder (para 22).

Indeed, the Portuguese rules seemed to have been sanctioned in the light of the free movement of capital due to the mere fact that the participation required for the application of these rules was only $10 \%$, and not necessarily because the term 'special relation' encompassed relations that did not require a shareholding in the borrowing company.

However, the Court concluded that:

It follows that a resident company may, irrespective of whether the lending company of the non-member country has a shareholding in it, or of the size of any such shareholding, rely upon the Treaty provisions on the free movement of capital in order to call into question the legality of such national rules (para 23).

Therefore, it seems that Croatian rules which do not apply solely to relations where the lending company has a decisive participation in the borrowing company could be sanctioned under the free movement of capital, which has a third country application.

In that case, it seems that the only way that the Croatian legislator could render the Croatian rules compatible with EU law is to extend their application also to purely national situations. This solution implies that the unfavourable tax treatment of excessive interest would be applicable regardless of where the lending company has its residence. 
This solution has an unwanted consequence. It entices companies to have recourse to external debt instead of intra-group debt. The conditions of these loans could be far less favourable than the intra-group ones would be, without there being a real threat of eroding the national tax base. As stated before, in purely national situations the interest deducted in the hands of the borrowing company is subsequently taxed in the hands of the lending company. ${ }^{46}$

This solution is also doubtful from the point of view of the European Commission:

In the Commission's view it would be regrettable if, in order to avoid the charge of discrimination, MSs extended the application of anti-abuse measures designed to curb cross-border tax avoidance to purely domestic situations where no possible risk of abuse exists. Such unilateral solutions only undermine the competitiveness of the MSs' economies, and are not in the interest of the Internal Market. Indeed, as AG Geelhoed observed in Thin Cap such an extension 'is quite pointless and indeed counterproductive for economic efficiency'. Moreover, it remains debatable whether such extensions can successfully bring all restrictive measures into line with the MSs' EC Treaty obligations. ${ }^{47}$

The last solution would be to apply the rules on transfer pricing and the arm's length principle to financial relations, also in terms of the amount of the loan, and not only the applicable interest rate. This is the case with the law in Great Britain. After the Thin Cap GLO case, the British lawmaker modified the national rules in such a way that it started applying transfer pricing rules instead of thin-capitalisation rules to financial relations between associated parties, including the amount of debt to which the deductible interest payments are linked.

Effectively, rules that would be thus constructed would conform to EU law in the sense that the Court has already decided that the application of the arm's length principle constitutes an objective test, according to which it is possible to verify whether the financial relation at cause is a purely artificial arrangement. This test needs to be applied to both national and cross-border relations. The solution, following the application of rules based on the arm's length principle, would be to disallow the

46 NP Bravo, 'Thin Capitalization Rules and EU Law/Fundamental Freedoms in C Massoner, A Storck and B Sturzlinger (eds), International Group Financing and Taxes (Linde Verlag 2012) 136.

47 Commission, The application of anti-abuse measures in the area of direct taxation within the EU and in relation to third countries' (Communication) COM(2007) 785 final, 6. 
deduction of interest which exceeds the amount of debt that would have be lent in relations between unrelated parties. ${ }^{48}$

Croatian law already applies the rules on transfer pricing to financial relations. ${ }^{49}$ However, these rules are applicable only to the assessment of the interest rate and not the amount of debt granted. The application of the arm's length principle, which is at the core of the transfer pricing rules, to the assessment of the amount of debt that would be granted between independent enterprises is not always easy to apply. Indeed, it presupposes the availability of information about the conditions under which unrelated parties would enter into a loan agreement.

Information concerning interest rates is publicly well known and it is sufficient to take a look at the easily accessible information pamphlets provided by the banks. On the other hand, the determination of the amount of debt which one person would allow to another independent person is a far more complex process. It takes into consideration the entire financial situation of a person, including the default risk, insolvency risk and other factors. This determination process could be a difficult task for the tax administration and a rather dangerous process for the taxpayer, since he/she could not necessarily find information on loans from other comparable enterprises in order to contest the tax administration's results. ${ }^{50}$ This could be detrimental to the principle of legal certainty of the taxpayer. In this sense, the author suggests that the legislator keep a fixed ratio approach, at the same time allowing the taxpayer to prove that notwithstanding the fact that he or she is in a position of being thinly capitalised, the amount of debt would still have been granted, under the same conditions, by an independent enterprise.

\section{Conclusion}

The Croatian rule on thin-capitalisation is contrary to EU law and it should be modified. The analysis of the Court's case law indicates that

\footnotetext{
48 N Vinther and E Werlauff, 'The Need for Fresh Thinking about Tax Rules on Thin Capitalization' (2003) 12(2) EC Tax Review 105

49 For the determination of the income from interest on loans granted by associated persons, the minimum calculated interest rate is the rate which would apply to non-associated persons at the time of granting a loan. For the determination of the expenditures for interest on loans received by associated persons, the maximum interest accrued is recognised at the interest rate which would apply to non-associated persons at the time of granting a loan. One could argue that Croatia does not in reality apply the arm's length principle because the interest rate referred to in this article is determined and published by the finance minister, prior to the beginning of the tax period in which it will be applied. If the Minister of Finance does not undertake any action, the applicable interest rate will be the discount interest rate fixed by the Croatian National Bank (art 14.3 CITA and art 37.2 of the Regulation).

50 CP Knöller, The Efficacy of Thin Capitalization Rules and Their Barriers: An Analysis from the UK and German Perspective (2011) 39(6/7) Intertax 6/7, 334
} 
the Croatian legislator has several options on how to make this rule 'euro-compatible'. The option to restrain its application solely to relations in which one of the parties is resident in a third country certainly represents a step forward in rendering the rule more 'euro-compatible'. However, since the rule is applicable also in situations in which the lender does not have a decisive participation in the borrowing company one could argue that this rule might be inspected under the scope of the free movement of capital, which has third country application.

The second solution would be to extend the field of application also to purely national situations. Nonetheless, as stated above, this solution is somewhat controversial from the viewpoint of the European Commission, since the extension of application to purely national situations which do not in reality represent a risk of abuse simply to avoid charges of discriminatory behaviour is deemed unproductive and even inefficient.

The replacement of thin-capitalisation rules with transfer pricing rules which are based on the arm's length principle seems indeed to be in line with the idea behind the case law of the European Court. Yet, this could provoke numerous questions in practice, elaborated above, which could even endanger the principle of the legal certainty of the taxpayer. This ought to be avoided at all cost.

Finally, what possible solution could there be to this problem? One solution might be to replace thin-capitalisation rules with so-called interest barrier rules. A thorough analysis of such rules is beyond the scope of this paper but could make for a topic of future research. 